\title{
Strategi Komunikasi Pemasaran Program Interaktif di Media Radio
}

\author{
Farid Rusdi \\ Fakultas Ilmu Komunikasi Universitas Tarumanagara
}

\begin{abstract}
Most of the radio stations today is involving the audiences through the interactive program. This changes is related with the reformation order, particulary in developing public sphere, meaning that society is more open than before. Some of the radio stations create this interactive program as their main positioning. In the competition among the radio station, marketing communication strategy is needed. This article discuss about how the station radio using the marketing communication strategy to win the competition.
\end{abstract}

Keywords : radio interactive program, marketing communication, strategy and practices.

\section{PENDAHULUAN}

Sebagian besar stasiun radio dalam siarannya selalu melibatkan pendengar dalam program radio interaktif, baik melalui fasilitas telepon, layanan pesan pendek, hingga blackberry messenger. Keterlibatan pendengar ini dalam program radio mulai marak setelah masa reformasi. Menurut Krishna Sen dalam Media, Budaya, dan Politik di Indonesia (2000), pada saat reformasi mulai bergulir, selain program pemberitaan yang kian marak, program talk-back atau program radio yang mengundang partisipasi pendengar melalui saluran telepon, cenderung mememiliki rating yang bagus. Terlebih jika program tersebut dianggap berani dan mau menyerang pemerintah. Sepanjang 1990an, ketika legitimasi pemerintah Soeharto mulai terkikis, program berita yang kritis dan program current affairs di radio tetap terperangkap di antara potensinya mendongkrak rating dan kompetisi yang semakin meningkat dari televisi.
Perubahan ini sangat mendukung semakin terbukanya ruang publik atau public sphere, di mana publik dapat berpartisipasi dan berinteraksi dengan berbagai kepentingan publik, melalui akses yang berimbang dan posisi berdialog yang berimbang. Mereka memperoleh kebebasan dalam mengemukakan pendapat secara proporsional, dan mendapatkan keragaman opini, visi dan perspektif.

Maraknya program-program interaktif di media radio selain karena semakin terbukanya keran demokrasi, juga karena perkembangan teknologi komunikasi. Pendengar dapat berinteraksi melalui telepon, faximili, email, dan saat ini dengan perkembangan teknologi, mulai menggunakan fasilitas layanan pesan pendek dari telepon genggam hingga blackberry messenger.

Di antara saluran-saluran komunikasi ini pendengar umumnya lebih banyak menggunakan telepon seluler. Setiap pendengar di manapun dia 
berada selama ia dapat mendengarkan stasiun radio yang menyelenggarakan program interaktif, ia dapat melibatkan diri di dalamnya dengan berinteraksi melalui telepon seluler, baik dengan saluran langsung maupun dengan pesan pendek.

Setelah reformasi, sejumlah radio swasta mengedepankan programprogram yang membuka ruang bagi demokratisasi. Pendengar dilibatkan untuk beropini atau menyampaikan informasi mengenai hal-hal yang mereka ketahuiyangtentunyatidakbisadilakukan pada masa orde baru. Radio Elshinta misalnya, membuka saluran pendengar untuk menyampaikan informasi apapun mengenai peristiwa yang terjadi di sekitar mereka. Para pendengar radio Elshinta dapat menyampaikan tentang peristiwa kecelakaan lalu lintas, kemacetan, kebakaran, dan peristiwa-peristiwa lainnya yang sangat bermanfaat bagi pendengar radio Elshintanya.

Radio Jakarta News FM (1998-2004), atau Radio Utan Kayu (Green Radio, 2005-sekarang) melibatkan pendengar untuk beropini dan berdiskusi di udara dalam program yang di selenggarakan. Para pendengarnya dibiarkan untuk berkomentar sebebas-bebasnya tentang isu-isu yang berkembang. Pada radio Jakarta News FM, pendengarnya lebih banyak beropini dan mengkritik kebijakan-kebijakan pemerintah. Pada Radio Utan Kayu yang mengedepankan demokrasi dan pemberdayaan masyarakat, mendorong kepada pendengarnya untuk berpendapat dan berdiskusi tentang berbagai wacana.

Radio Trijaya (Sindo Radio, September 2011-sekarang) adalah salah satu radio swasta di Jakarta yang melibatkan publik hampir di setiap programnya. Pendengar diminta untuk memberikan respons terhadap hampir setiap program yang disiarkan. Pendengar dapat memberikan pertanyaan, jawaban, dan pendapat tanpa dibatasi seperti di masa orde baru.

Dalam program-programnya Radio Trijaya menyediakan berita-berita yang sebagian besar terkait dengan kebijakan pemerintah, sering meminta pendapat dari pendengarnya, yang kadang pendapat tersebut turut mempengaruhi pandangan orang lain yang sedang mendengarkan Radio Trijaya saat itu.

Namun sebagai radio yang berorientasi mencari keuntungan, tentu tidak bisa lepas dari kepentingan ekonominya. Public sphere yang diharapkan tumbuh berkembang seiring dengan roda reformasi, ternyata sedikit demi sedikit tergeser oleh kepentingan untuk meraih keuntungan. Pengiklan menjadi sumber penghasilan dan bukan dari pendengar. Akibat motivasi pengelola untuk mencari keuntungan maka radio lebih tampak sebagai institusi komersial murni ketimbang institusi yang netral atau bersikap selektif.

Aktor strategis di media radio dalam konteks ekonomi adalah pengiklan, organisasi bisnis danindividu yang memiliki modal. Sedangkan aktor strategis dalam konteks sosial di media radio adalah masyarakat pendengar yang beragam dalam lingkup jangkauan siar radio setempat. Dalam mengambil keputusan suatu siaran idealnya diperlukan pemikiran yang menyeimbangkan kepentingan kedua belah pihak tersebut (Masduki, 2004).

Dedy N Hidayat dalam buku Penyiaran Alternatif tapi Mutlak, yang disusun Effendi Gazali (2002) mengungkapkan bahwa industri penyiaran yang baru saja terlepas dari 
kontrol dan intervensi pemerintah di masa Orde Baru, ternyata kini beroperasi melalui the invisible hand mekanisme pasar dengan logika never-ending circuit accumulation: M-C-M (MoneyCommodities-More-Money). Hal ini akibat dari liberalisasi industri penyiaran yang terjadi pasca runtuhnya Orde Baru, yaitu peralihan dari regulasi indutri penyiaran oleh negara menjadi regulasi penyiaran oleh pasar.

Namun demikian jika sebuah stasiun radio terlalu banyak menayangkan iklan dalam siarannya, para pendengarnya akan meninggalkan stasiun radio itu dan berpindah ke stasiun lainnya. James Duncan, Presiden Duncan's American Radio seperti dikutip oleh Alex Kuczynski dalam artikelnya 'Radio Squeezes Empty Space for Profit' mengatakan ada batas maksimum bagi para pendengar untuk dapat menerima iklan-iklan yang terus disiarkan oleh stasiun-stasiun radio. Menurut Duncan, para pemilik stasiun radio harus dapat menyadari hal ini, karena jika tidak para minat pendengar terhadap stasiun-stasiun radio mereka menjadi menurun.

Selain itu radio yang terlalu banyak iklan dalam penyiarannya belum tentu dapat menjangkau targetnya. Iklan yang banyak memang menguntungkan bagi pengelola radio. Tapi terlalu banyak iklan dalam satu jam program, dikeluhkan pula bukan hanya oleh si pendengar tapi oleh si pemasang iklan, karena iklannya tidak efektif. (Kuzynski, 2000)

Rush Limbaugh, pemilik program talkshow radio di Amerika Serikat, The Rush Limbaugh Show seperti dikutip Kuzynski, mengatakan tidak ada orang yang mau mendengarkan sebuah program radio dimana 30 menit dari setiap 60 menit program itu adalah berisi iklan. Tidak ada pemasang iklan yang ingin iklannya dihimpit di antara enam iklan lainnya.

Dari uraian di atas dapat dipahami bahwa pengelolaan media saat ini tidak bisa mementingkan satu pihak saja. Pengelola radio membutuhkan pengiklan untuk operasional siarannya. Namun jika radio terlalu mementingkan pengiklan maka pendengar tentu merasa ruangnya untuk beraspirasi dan beropini semakin sempit dan meninggalkan radio itu untuk mencari radio lain. Pendengar dan pengiklan memiliki kepentingan masingmasing dalam memanfaatkan media. Oleh karena itu diperlukan pengelolaan yang tepat sehingga kepentingan kedua pihak dapat menjadi keuntungan bagi pengelola radio.

Dalam bisnis radio, pengiklan adalah sebagai customer yang sesungguhnya. Clear Channel Communication, sebuah perusahaan industri radio di Amerika Serikat, menekankan dalam bisnis radio adalah menjual pendengar atau audience kepada para pengiklan, bukan menjual radio atau musik. (Straubhaar, La Rose, 2006) 


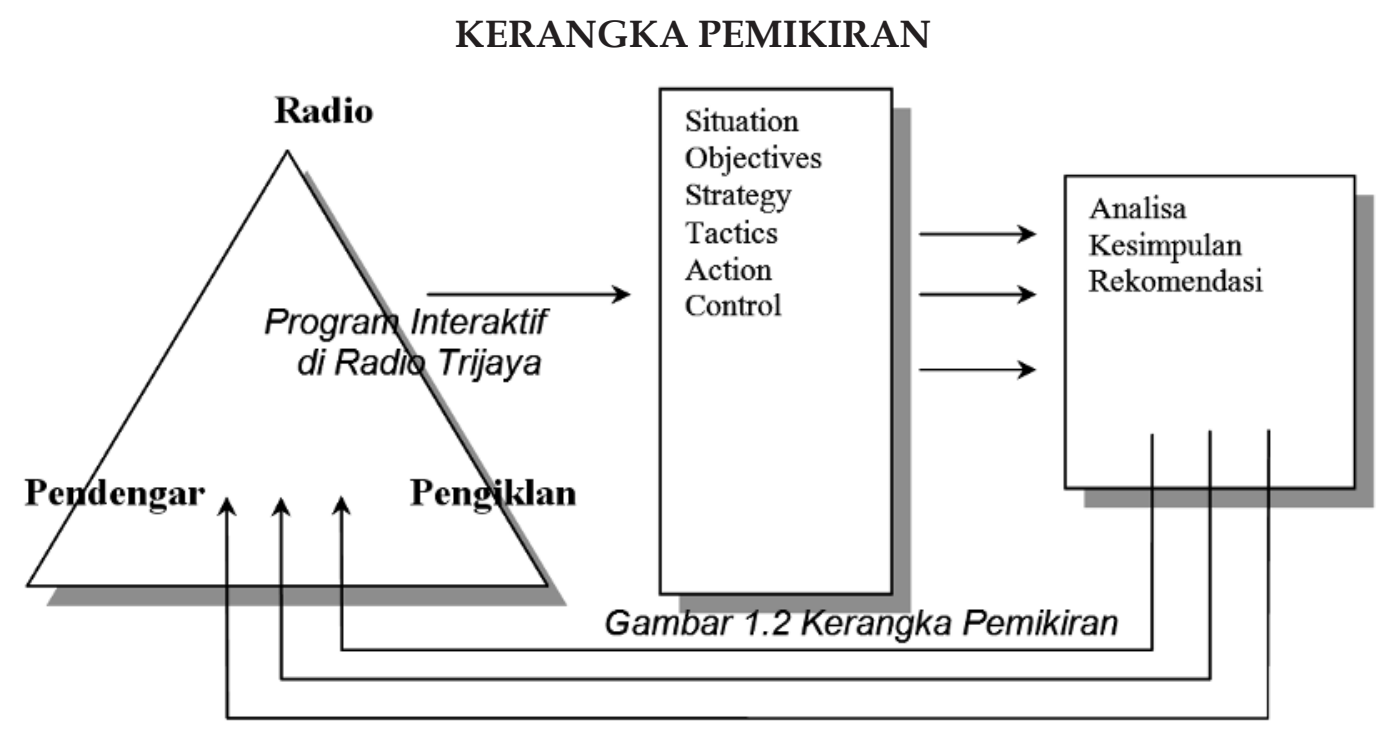

Dalam menjalani kegiatannya, Radio Trijaya menghadapi dua pihak yang memiliki kepentingan yang berbeda. Dua pihak itu adalah pendengar dan pengiklan. Pendengar selain ingin memperoleh informasi dan hiburan, mereka ingin juga berpartisipasi dalam program-program Trijaya. Pengelola radio membuka ruang dan mengundang pendengar untuk berinteraktif dalam sejumlah program. Semakin banyak pendengar yang tertarik berinteraksi, semakin tertarik pula pengiklan untuk memasang iklan di program itu. Kedua pihak sama diperlukan oleh pengelola radio.

Dalam penelitian ini strategi komunikasi pemasaran dari pengelola radio dianalisa melalui analisis SOSTAC. Hasil dari analisa didiskusikan dengan teori-teori komunikasi pemasaran. Pada akhirnya peneliti akan membuat kesimpulan dan rekomendasi terhadap proses strategi komunikasi pemasaran program interaktif di radio Trijaya.

Dalam menjalani kegiatannya, Radio Trijaya menghadapi dua pihak yang memiliki kepentingan yang berbeda. Dua pihak itu adalah pendengar dan pengiklan. Pendengar selain ingin memperoleh informasi dan hiburan, mereka ingin juga berpartisipasi dalam program-program Trijaya. Pengelola radio membuka ruang dan mengundang pendengar untuk berinteraktif dalam sejumlah program. Semakin banyak pendengar yang tertarik berinteraksi, semakin tertarik pula pengiklan untuk memasang iklan di program itu. Kedua pihak sama diperlukan oleh pengelola radio.

Dalam penelitian ini strategi komunikasi pemasaran dari pengelola radio dianalisa melalui analisis SOSTAC. Hasil dari analisa didiskusikan dengan teori-teori komunikasi pemasaran. Pada akhirnya peneliti akan membuat kesimpulan dan rekomendasi terhadap proses strategi komunikasi pemasaran program interaktif di radio Trijaya.

R. G. Picard, sebagaimana dikutip oleh Alan B. Albaran dalam buku Media Economics: Understanding Markets, Industries and Concepts menjelaskan bahwa industri media itu unik karena memiliki fungsi dalam dua pasar sekaligus, yaitu berkecimpung dalam pasar produk dan jasa. Di pasar yang pertama, radio memasarkan produknya berupa content atau isi yang ditawarkan 
kepada pendengarnya. Pasar yang kedua adalah penjualan kepada pemasang iklan yang ingin mencapai khalayak dari media yang bersangkutan. (Albaran, 1996)

Kepentingan atau kebutuhan dari pelanggan dalam hal ini pendengar dari pengiklan merupakan salah satu pilar dari empat pilar dalam konsep pemasaran. Pilar lainnya dalam konsep pemasaran adalah pasar sasaran, pemasaran terintegrasi dan laba melalui kepuasan pelanggan. Konsep pemasaran menegaskan bahwa kunci untuk mencapai tujuan organisasional yang ditetapkan adalah perusahaan tersebut harus menjadi lebih efektif dibandingkan para pesaing dalam menciptakan, menyerahkan dan mengkomunikasikan nilai pelanggan kepada pasar sasaranyang terpilih. Konsep pemasaran mempunyai perspektif dari luar ke dalam. Konsep itu dimulai dari pasar yang didefinisikan dengan baik, berfokus pada kebutuhan pelanggan, mengkoordinasikan semua aktivitas yang akan mempengaruhi pelanggan, dan menghasilkan laba dengan memuaskan pelanggan. (Kotler, 2002)

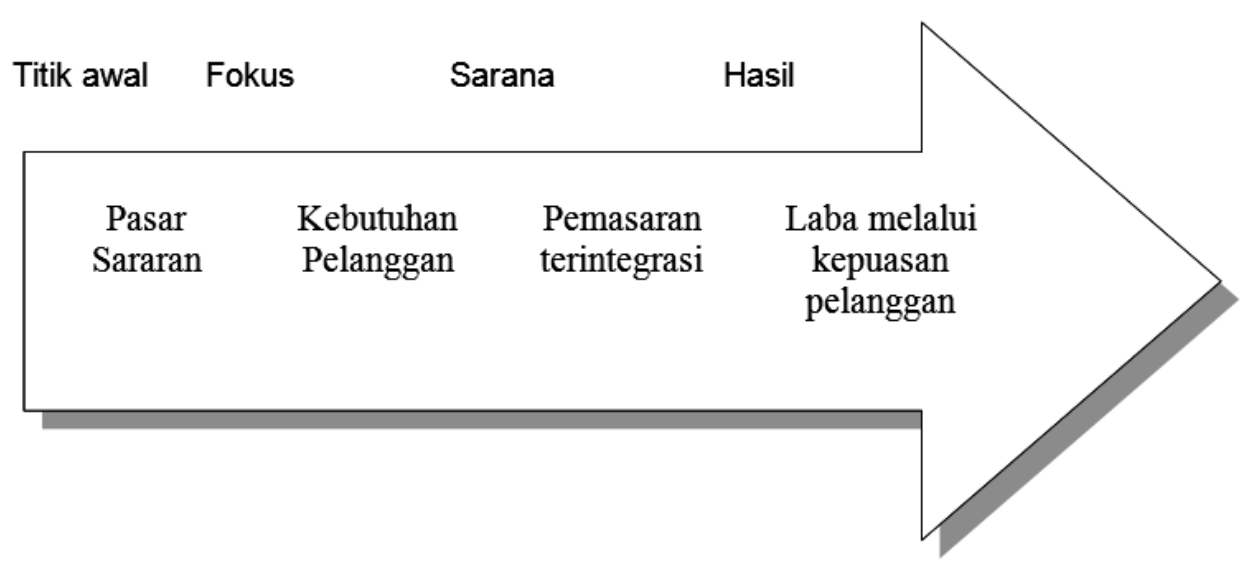

\section{Gambar 1.1 Konsep Pemasaran}

(Sumber: Kotler, 2002)

\section{Radio}

Radio adalah sebuah institusi yang kompleks. Ia terkait dengan berbagai hal di luar yang mempengaruhi dirinya dalam melakukan siaran. Radio sebagaimana media komunikasi massa lainnya tidak berada di 'ruang hampa', tetapi berada di dalam komunitas masyarakat yang heterogen dengan segala macam kompleksitas permasalahan (Masduki, 2004)

Sebagai sebuah bisnis, radio melibatkan berbagai pihak. Pertama, sebagai media massa, radio tersebut harus mampu mengumpulkan khalayak yang jumlahnya signifikan dengan cara memberikan apa yang dibutuhkan oleh mereka. Kedua, ia harus mampu menarik iklan untuk menjaga keberlangsungannya secara finansial. Ketiga, ia harus dapat memuaskan pihak pemilik radio yang mengharapkan radio menjadi usaha yang mendatangkan laba atau keuntungan.

R. G. Picard, sebagaimana dikutip oleh Alan B. Albaran dalam buku Media Economics: Understanding Markets, Industries and Concepts menjelaskan bahwa industri media itu unik karena 
memiliki fungsi dalam dua pasar sekaligus, yaitu berkecimpung dalam pasar produk dan jasa. Di pasar yang pertama, radio memasarkan produknya berupa content atau isi yang ditawarkan kepada pendengarnya. Pasar yang kedua adalah penjualan kepada pemasang iklan yang ingin mencapai khalayak dari media yang bersangkutan. (Albaran, 1996)

Dalam olah siarannya, radio memiliki material dasar berupa siaran musik dan kata. Material ini diproses melalui transmisi teknologi dan pemrograman kreatif kepada publik tanpa mengenal pretensi spesifik meski ada pendengar tertentu yang dituju. Ketika melakukan proses on air, seorang penyiar pada hakikatnya berkomunikasi dengan suatu lingkungan sosial lain atas nama institusi radio. Ia tidak sendirian. Interaksi radio dengan lingkungannya bersifat antar-institusi sehingga dalam konteks itu dapat terdapat konsekuensi etik yang harus dipatuhi bersama. Konsekuensi itu adalah tanggung jawab sosial sebagai media massa dalam ikut serta menjalin harmoni yang tinggi, tidak menciptakan kekacauan di ruang publik. Radio harus memiliki kode etik berupa sikap obyektif, seimbang, informasi yang edukatif, serta pertimbangan yang selalu memperhatikan dampak positif dan negatif sebuah acara sebelum dipilih untuk ditayangkan (Masduki, 2004).

Poerbojopoetro dan Moeryanto Ginting sebagaimana dikutip oleh Masduki dalam Menjadi Broadcaster Profesional mengatakan fungsi dari program interaktif adalah:

1. Sebagai alat ukur sampai di mana siaran bisa diikuti, dipahami dan menggugah keaktifan pendengar.

2. Sebagai sumber otentik untuk mengetahui, mendapatkan gambaran kebutuhan, dan masalah yang dihadapi pendengar.

3. Sebagai saluran untuk melibatkan pendengar dan menumbuhkan keakraban (sense of belonging).

Dari uraian di atas dapat dipahami bahwa program interaktif mendekatkan pendengar dengan radio yang ia dengar. Pendengar ingin aktif dalam siaran-siaran yang diselenggarakan pengelola radio. Sementara pengelola radio menjadi lebih mengenal bagaimana karakteristik para pendengarnya untuk menjadi referensi dalam membuat program-progam lain misalnya. Selain itu pendengar semakin loyal terhadap radio itu, karena adanya kedekatan baik dengan pihak pengelola radio atau dengan para pendengar lainnya yang juga berinteraktif di radio itu.

Namun, dalam operasionalnya dengan mengedepankan kepentingan publik, radio dapat mengalami kesulitan danajika ia mengenyampingkan kekuatan pasar. Karena radio seperti juga televisi memperoleh penghasilannya dari iklan. Dalam persaingan media elektronik yang semakin ketat saat ini, upaya untuk meraih pangsa iklan semakin gencar. Dari perbandingan kue iklan, media televisi mendapatkan kue iklan terbesar dengan lebih dari enampuluh persen. Sementara radio mendapatkan sekitar lima persen. Dan itu pun harus diperebutkan oleh delapan ratus lebih stasiun radio di Jakarta dan ditambah dengan ratusan radio di daerah.

Para peneliti interaktifitas media menggolongkan radio, televisi dan media cetak memiliki tingkat interaktifitas yang rendah dibandingkan media-media baru seperti komunikasi komputer melalui sistem pesan elektronik, teleconference melalui komputer, televisi kabel interaktif 
dan lain sebagainya. Rogers (1986, dalam Jensen, 1999) mendefinisikan interaktif sebagai :

"the capability of new communication systems (usually containing a computer as a one component) to 'talk back' to the user, almost like an individual participating in a conversation' and interactivity is a variable; some communication technologies are relatively low in their degree of interactivity (for example, network television), while others (such as computer bulletin boards) are more highly interactive."

Rogers membuat ukuran tingkat interaktifitas terhadap sejumlah teknologi media antara dari yang rendah hingga yang tinggi.

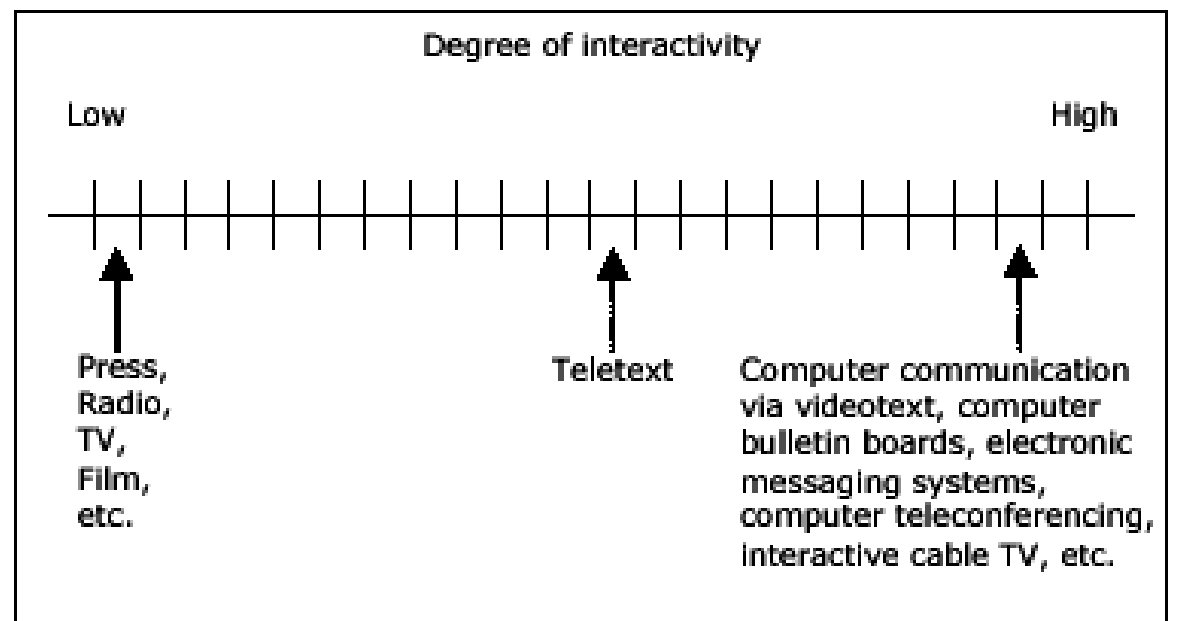

\section{Gambar 2.3 Degree of interactivity}

(Sumber: Loes De Vos, 2000)

Sementara Laurel (1991) dalam Jensen (1999) berpendapat bahwa interaktifitas dapat dikarakteristik oleh tiga variabel, yaitu frekuensi, cakupan dan signifikansi. Frekuensi yaitu seberapa sering si pengguna media dapat bereaksi. Cakupan yaitu seberapa banyak pilihan yang tersedia. Signifikansi yaitu sejauh mana dampak dari pilihan-pilihan tersebut. Hasil dari ketiga variabel ini bahwa tingkat interaktifitas yang rendah adalah saat si pengguna hanya mempunyai kesempatan yang sedikit untuk bertindak, karena sedikitnya pilihan-pilihan yang ada dan dampak dari pilihan-pilihan itu sedikit atau bahkan tidak ada. Sementara tingkat interaktifitas yang tinggi ada pada saat si pengguna dapat sering bertindak, dan memiliki banyak pilihan yang secara signifikan berpengaruh. 


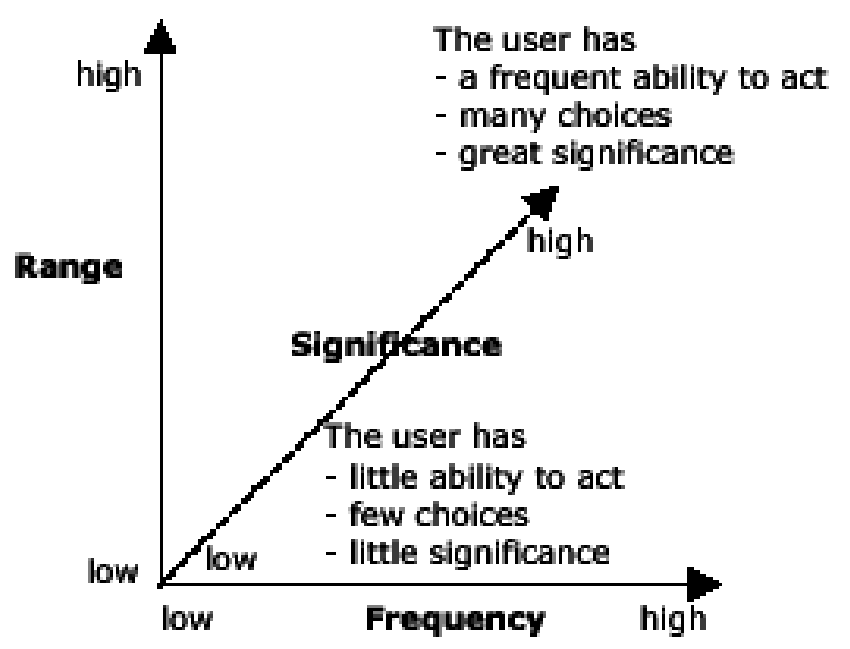

\section{Gambar 2.4 3-dimensional continuum of interactivity}

(Sumber: Loes De Vos, 2000)

Dariuraian diatas dapat disimpulkan bahwa interaktifitas di media tradisional seperti TV dan radio walaupun belakangan ini marak, ternyata tingkat interaktifitasnya rendah dibandingkan media baru. Interaktifitas di media tradisional menyediakan pilihan-pilihan yang terbatas untuk penggunanya, berbeda dengan komunikasi komputer yang menawarkan banyak pilihan bagi penggunanya.

\section{Program Interaktif di Radio}

Program atau programme merupakan produk dari media radio. Produk seperti yang diungkapkan Kotler adalah setiap tawaran yang dapat memuaskan kebutuhan dan keinginan (Kotler, 2000). Pengelola radio melalui programnya berupaya meraih pendengar sebanyak-banyaknya. Semakin banyak pendengar yang ia raih maka semakin banyak pengiklan yang tertarik untuk memasang iklannya di radionya. Oleh karena itu pengelola radio harus dapat menghasilkan program yang bermutu dan inovatif.

Program interaktif di radio dalam penelitian ini adalah program atau acara di radio yang melibatkan partisipasi pendengar. Pendengar diberi ruang oleh pengelola program untuk menyampaikan aspirasi, opini, dan pertanyaan atas materi yang disiarkan. Partisipasi pendengar itu disampaikan melalui sarana komunikasi yang ada pada pendengar maupun radio. Umumnya stasiun-stasiun radio membuka saluran telepon. Jika pendengar merasa sulit untuk memperloleh sambungan ke studio karena banyaknya pendengar yang juga ingin berpartisipasi, maka ia dapat mengirimkan aspirasinya dengan SMS atau pesan pendek ke nomor telepon yang telah disebutkan oleh penyiar. Pada saatnya nanti si penyiar akan membacakan isi pesan pendek tersebut di udara. Atau jika isi pesan pendek itu adalah pertanyaan maka akan diteruskan kepada narasumber untuk dijawab. Hal yang sama juga berlaku pada surat, faximili ataupun surat elektronik atau 
e-mail.

Menurut Dennis List, peneliti dan praktisi radio di Australia, dalam bukunya Pemasaran Partisipatif Untuk Radio Lokal, program interaktif adalah program yang populer di media radio. Pendengar radio saat ini tidak ingin hanya menjadi pendengar yang pasif. Mereka ingin terlibat aktif dalam program yang disiarkan oleh pengelola radio. Angka survei pendengar biasanya menunjukkan dengan sangat jelas program radio yang sangat populer adalah program interaktif. (List, 2003)

Demikian pula dengan praktisi dan akademisi jurnalistik radio, Masduki, yang mengatakan dalam dua puluh tahun terakhir, program interaktif merupakan program radio yang populer di berbagai negara termasuk Indonesia. Ia mencontohkan, pada radio yang bersegmen pendengar anak muda. Program interaktif populer adalah pelayanan permintaan lagu (song request), kuis, perbincangan bebas seputar gosip, curahan hati (curhat), hingga permainan yang menggugah rasa humor. Selain menggoda karena iming-iming hadiah hiburan atau cuma sekedar ingin tampil di udara untuk menyapa pendengar lain, acara interaktif juga mampu menghadirkan suasana meriah di hati pendengar. (Masduki, 2004)

Poerbojopoetro dan Moeryanto Ginting sebagaimana dikutip oleh Masduki dalam Menjadi Broadcaster Profesional mengatakan fungsi dari program interaktif adalah:

1. Sebagai alat ukur sampai di mana siaran bisa diikuti, dipahami dan menggugah keaktifan pendengar.

2. Sebagai sumber otentik untuk mengetahui, mendapatkan gambaran kebutuhan, dan masalah yang dihadapi pendengar.

3. Sebagai saluran untuk melibatkan pendengar dan menumbuhkan keakraban (sense of belonging).

Dari uraian di atas dapat dipahami bahwa program interaktif mendekatkan pendengar dengan radio yang ia dengar. Pendengar ingin aktif dalam siaran-siaran yang diselenggarakan pengelola radio. Sementara pengelola radio menjadi lebih mengenal bagaimana karakteristik para pendengarnya untuk menjadi referensi dalam membuat program-progam lain misalnya. Selain itu pendengar semakin loyal terhadap radio itu, karena adanya kedekatan baik dengan pihak pengelola radio atau dengan para pendengar lainnya yang juga berinteraktif di radio itu.

\section{Analisis SOSTAC}

Untuk mengidentifikasi dan menganalisa strategi komunikasi pemasaran radio Trijaya dalam mengelola partisipasi pendengar di sejumlah programnya, peneliti menggunakan model SOSTAC, yang dikembangkan oleh pakar pemasaran Paul R Smith pada tahun 1990-an.

Analisis SOSTAC dapat menganalisis strategi komunikasi pemasaran secara lebih spesifik. Kelebihan analisis SOSTAC adalah dapat menganalisis strategi yang ada dengan lebih baik melalui tahapan-tahapan dalam analisis SOSTAC yang dapat menghasilkan solusi dan pertimbangan terhadap suatu masalah. Tujuan SOSTAC adalah agar pelaku pemasaran dapat memahami secara pasti apakah strategi komunikasi pemasaran yang mereka jalankan sudah sesuai bagi perusahaan atau belum. Prediksi keberhasilan strategi dan taktik komunikasi pemasaran terpantau dengan 
adanya dimensi-dimensi SOSTAC sebagai suatu analisis praktik promosi dan komunikasi pemasaran

\section{A. Situation}

Program interkatif di media radio dalam segi efiensi dan kecepatan memiliki kelebihan dibanding media lain. Karena selain biaya untuk penyelelenggaraan program interaktif yang murah, juga penyiapannya lebih cepat dan ringkas, karena hanya memanfaatkan masuknya telepon dan pesan pendek atau sms. Radio hanya mengedepankan suara dan tutur kata. Berbeda dengan media $\mathrm{TV}$, yang memerlukan gambar untuk program interaktifnya. Sementara media cetak, seperti melalui artikel 'Surat Pembaca' nya, memerlukan waktu lebih lama untuk proses interaktifnya.

Program-program radio Trijaya hampir semuanya menyisipkan program interaktif. Mereka memberikan kesempatan kepada pendengar untuk menanggapi program-programyang telah diudarakan. Semakin banyak pendengar yang terlibat dalam suatu program, semakin tertarik pihak pengiklan untuk memasang iklannya di program itu.

Untuk mengetahui keadaan program Interaktif khususnya terhadap dua program di Trijaya yaitu Indonesia First Channel dan Jakarta First Channel sebagai sebuah produk, dapat dianalisa melalui Marketing Mix (Product, Price, Place, Promotion):

1. Product: Program Indonesia First Channel, Jakarta First Channel dan Parliament on Radio adalah program talk show yang membahas isuisu aktual dengan menghadirkan narasumber yang berkompeten di bidangnya. Dalam program ini pendengar diundang untuk berpartisipasi untuk menyampaikan pendapatnya tentang isu-isu aktual yang diangkat Selain itu pendengar juga bertanya dan berdialog langsung kepada narasumber yang tengah dihadirkan saat itu. Program-program ini disiarkan pada jam prime time, yaitu waktu yang menurut perhitungan pengelola Trijaya didengar oleh lebih banyak pendengar Trijaya.

2. Price : Harga pemasangan iklan di radio Trijaya di atas rata-rata radioradio swasta di Jakarta. Namun bukan yang termahal.

3. Place: Gelombang 104.6 Mhz, berkekuatan $10 \mathrm{KW}$, yang dapat dengan mudah dijangkau oleh para pendengar di Jakarta yang memiliki tape radio FM dengan harga yang murah. Selain pendengar di Jakarta, siaran Trijaya melalui jaringannya dapat menjangkau pendengarnya radio di daerah-daerah. Sepertimelalui radio SCFM Trijaya Surabaya, Trijaya FM Bandung, Trijaya FM Semarang, Trijaya FM Yogyakarta, Prapanca FM Medan, dan beberapa radio lainnya di sejumlah daerah.

Program Jakarta First Channel dan Indonesian First Channel disiarkan pada jam tujuh hingga sembilan pagi, dimana saat itu merupakan jam yang mendapat perhatian pendengar cukup tinggi. Pengelola radio memperkirakan pendengar radio Trijaya yang ditargetkan dari kalangan profesional muda, pada jamjam itu sedang berkendara menuju tempat kerja sambil mendengarkan radio.

4. Promotion: Peneliti menemukan kegiatan promosi kepada tentang kedua program hanya berupa promosi melalui media itu sendiri yaitu radio 
Trijaya atau Radio Expose. Promo itu disiarkan setiap hari bersamaan dengan materi iklan lainnya. Dalam promo itu disebutkan selain waktu siar program, juga di sebutkan topik yang akan dibahas bersama dengan narasumber yang hadir dalam program tersebut. Pendengar diundang untuk berpartisipasi dalam program.

Promo melalui media sendiri ini selain berdampak pada pendengar, juga berdampak pada pengiklan. Kepada pengiklan, promosi dilakukan pula oleh marketing dan sales Trijaya melalui penjualan personal, dan direct marketing.

Untuk mengetahui faktor eksternal di luar perusahaan maka dapat dilakukkan analisis eksternal, yaitu melalui analisis STEP (Sosiological, Technological, Economical, dan Political):

- Sosiological : Setiap orang ingin pemikirannya didengar, bukan hanya didengar oleh sekelompok kecil, tapi juga orang banyak. Melalui program interaktif keinginan dari sebagian masyarakat ini dapat disalurkan.

- Technological :Perkembangan teknologi komunikasi yang pesat semakin mempermudah setiap orang untuk menyampaikan pesan kepada siapapun dimana pun. Telepon seluler dan pesan pendeknya semakin memperlancar proses interaktif program radio. Setiap pendengar dimanapun posisinya selama ia masih bisa mendengarkan program radio itu, maka ia dapat terlibat di dalamnya.

- Economical: Kondisi ekonomi yang mulai membaik, daya beli masyarakat semakin meningkat. Para pengiklan perlu media untuk menjangkau kon- sumennya. Belanja iklan dalam beberapa tahun terakhir terus mengalami peningkatan.

- Political: Setelah reformasi, pemerintah tidak lagi mengontrol isi media. Media dapat menaikkan topik-topik yang mengkritik pemerintah secara terbuka. Publik juga semakin awas terhadap isu-isu politik, ekonomi serta kebijakan publik yang dirasakan tidak adil.

\section{B. Objectives}

Visi radio Trijaya adalah sebagai salah satu badan hukum yang bersifat komersil bertujuan mencari keuntungan, memperoleh keuntungan sebanyakbanyaknya dengan sasaran segmentasi. Selain itu radio Trijaya mencoba untuk mengemban tugas pembelajaran kepada masyarakat untuk meningkatkan pengetahuan masyarakat di dalam berbangsa dan bernegara, dengan kata lain menjadi warga negara yang baik.

Misi radio Trijaya adalah mencoba untuk memberikan informasi yang baik dan benar kepada pendengar, memberikan hiburan yang sehat kepada masyarakat, serta membentuk karakter masyarakat Indonesia menjadi bangsa yang berakhlak baik.

Dalam visi dan misinya Radio Trijaya FM menekankan pada poin penting yaitu memperoleh keuntungan sebanyakbanyaknya dengan sasaran segmentasi. Selain itu menghibur dan memberikan pembelajaran kepada masyarakat Indonesia.

Segmentasi menjadi tujuan utama bagi pengelola Radio Trijaya FM. Dengan sapaan 'Profesional Muda' kepada para pendengarnya, Trijaya menargetkan pendengarnya dari kalangan masyarakat berumur antara 25-45 tahun, pria dan 
wanita dengan tingkat pendidikan Diploma III hingga Strata Satu, dengan tingkat sosial ekonominya menengah ke atas, dan dengan status campuran antara menikah dan belum menikah.

Tujuan dari adanya program interaktif di radio Trijaya sebagaimana diungkapkan oleh Station Manager Trijaya, Tias Anggoro, adalah untuk memberi ruang kepada publik untuk berpendapat tentang suatu topik, sehingga radio Trijaya dapat menjadi saluran komunikasi Publik. Selain itu pendengar juga dapat berinteraksi dengan narasumber yang dihadirkan Trijaya dalam program-program talkshow-nya.

Jika melihat visi dan misi dari radio Trijaya, maka tujuan diadakannya program interaktif di radio Trijaya adalah menjaring pendengar yang sesuai dengan segmentasinya untuk kepentingan menarik pengiklan. Selain itu membuka ruang bagi publik untuk berkomunikasi sebagai bentuk pembelajaran kepada masyarakat di dalam berbangsa dan bernegara.

Dengan demikian tujuan dari komunikasi pemasarannya adalah untuk mengkomunikasikan program kepada pendengar dan pengiklan melalui saluran komunikasi yang ada sehingga mempengaruhi tanggapan mereka terhadap program.

Apa telah diuraikan di atas dapat dikaji denganSMART(Spesific, Measurable, Achievable, Realistic, Time-related):

1. Spesific : Tujuan diadakannya program interaktif melalui program Indonesia First Channel dan Jakarta First Channel di Trijaya sudah spesifik, yaitu untuk meningkatkan pengetahuan pendengar Trijaya, memberi kesempatan pendengar berinteraksi dengan narasumber yang hadir, menjaring pendengar untuk berinteraktif sesuai segmentasi yang dituju yaitu kalangan profesional muda, dan menarik pengiklan.

2. Measureable: Ada bagian dari tujuan tidak terukur dengan jelas, yaitu peningkatan pengetahuan pendengar Trijaya, karena tidak dapat diketahui apakah program yang disiarkan benarbenar bermanfaat bagi pendengar atau tidak.

3. Achievable: Tujuan itu sudah tercapai. Program interaktif yang ada telah mengundang banyak pendengar untuk mengungkapkan pendapatnya dan berinteraktif dengan narasumber. Bersamaan dengan itu, pengiklan tertarik memasang iklannya pada program tersebut.

4. Realistic : Program interaktif relevan untuk dimanfaatkan di media radio sebagai saluran komunikasi publik, karena situasi politik yang sudah jauh lebih demokratis. Dan ini merupakan bentuk pembelajaran kepada masyarakat untuk berdemokrasi.

5. Time-related : Tujuan tidak memiliki ada kisaran waktu yang jelas. Namun jika evaluasi program enam bulanan dijadikan kisaran waktu, maka tujuan memiliki rentang waktu enam bulan.

\section{Strategy}

Untuk mencapai tujuannya, pengelola radio Trijaya berupaya untuk meningkatkan komunikasi dengan pengiklan dan agensi. Selain itu meningkatkan awareness pendengar terhadap program, yaitu dengan cara meningkatkan kualitas program.

Strategi promosi yang dilakukan yaitu melalui pull strategy berupa promosi melalui radio expose (RE) di media sendiri, radio Trijaya. Strategi ini adalah untuk 
mengkomunikasikan program kepada pendengar. Selain itu juga penyiar membacakan ad-lib tentang tema yang angkat pada program JFC, IFC, dan PoR.

Sementara melalui push strategy, yaitu promosi yang dilakukan kepada pengiklan, berupa peran sales dan marketing untuk mengkomunikasikan program yang bertujuan untuk mempengaruhi pengiklan untuk memasang iklannya di program itu atau membeli air time pada program itu. Selain itu sales dan marketing dapat mendorong dan membujuk agensi untuk mempromosikan program kepada pengiklan agar membeli air time pada program itu.

\section{Tactics}

Untuk meningkatkan kualitas program, produser selalu berupaya menghadirkan narasumber yang kredibel dan kompeten sebagai pembicara. Dan untuk menambah tajamnya pembahasan, dihadirkan pula moderator tamu dari media massa.

Dalam pesan yang disampaikan kepada pendengar melalui RE, disebutkan nama narasumber yang hadir dalam program. Hal ini sebagai daya tarik bagi para pendengar. Demikian juga pada ad-lib yang dibacakan penyiar.

Sementara, upaya untuk mengkomunikasikan program dengan para pengiklan dan agensi terus ditingkatkan, yaitu dengan melalui pendekatan personal, pemasaran langsung, kepada pengiklan dan agensi.

\section{E. Actions}

RE kedua program disiarkan setiap hari terutama pada jam-jam pendengar radio dari kalangan profesional muda sedang mendengarkan radio seperti jam makan siang dan pulang kerja.

Untuk pengiklan dan agensi, informasi mengenai program ditambah. Selain data dari lembaga survey pendengar seperti AC Nielsen, juga perlu ditambah dengan data-data hasil riset internal Trijaya, termasuk data jumlah SMS dan telepon yang masuk dari pendengar untuk program tersebut.

\section{F. Control}

Evaluasi terhadap programprogram yang ada dilakukan setiap enam bulan sekali. Setahun sekali juga dilakukan rapat perubahan pola siar secara keseluruhan yang didalamnya mengagendakan mengevaluasi program yang sudah berjalan. Hal ini sebagaimana diungkapkan oleh Tyas Anggoro Station Manager Trijaya:

“Evaluasi dilakukan terhadap program itu kita lakukan secara berkala. Biasanya enam bulan sekali. Dan setahun sekali kita melakukan evaluasi terhadap pola siar secara keseluruhan. Tidak pada programprogram tertentu. Tapi pada pola siar secara keseluruhan. Apa yang ingin dicapai, kita ingin pendengar kita itu mendapat sesuatu yang selalu bermanfaat, supaya mereka tidak jenuh. Terkadang kalau kita berikan itu-itu melulu, berapa banyak sih pendengar yang akan loyal terus menerus dengan pola seperti itu. Mereka pasti ingin sesuatu yang baru, yang lain, yang kita berikan."

\section{DISKUSI}

Pengelola radio harus dapat menyeimbangkan dua kepentingan, yaitu pendengar dan pengiklan. Pendengar ingin mendapatkan haknya melalui radio. Sementara pengiklan ingin produknya dikenal oleh masyarakat yang sebagian ada di antara pendengar radio itu. Pengelola radio pun memiliki 
kepentingannya sendiri yaitu mencari keuntungan dari dua kepentingan ini.

Pendengar radio di masa demokrasi sekarang ini, menginginkan lebih dari sekedar menikmati musik dan informasi dari radio. Mereka juga ingin haknya di ruang publik digunakan. Mereka ingin bersuara menyampaikan aspirasi dan pendapat mereka terhadap permasalahan mulai dari sekitar mereka hingga permasalahan nasional.

Melalui saluran telepon dan short messages sevice (SMS), keinginan pendengar ini dapat tersalurkan. Pihak pengelola radio memanfaatkan peran serta pendengar untuk meramaikan program-program mereka. Semakin banyak pendengar yang terlibat dalam program itu, semakin tinggi minat para pengiklan untuk hadir dalam program.

Kehadiran para pengiklan sangat diharapkan oleh pengelola radio. Karena penghasilan radio diperoleh dari para pengiklan. Radio Trijaya sebagai radio komersil yang mencari keuntungan, sangat membutuhkan iklan sebanyakbanyaknya.

Untuk memikat pendengar, pengelola radio harus mengenal target pendengarnya sehingga produk yang dipersiapkan benar-benar sampai pada yang ditujukan. Pengidentifikasian target pendengar bukan hanya untuk penyiapan produk, tapi juga peyiapan pesan-pesan kepada target tentang produk.

Menurut Kotler (2002), agar komunikasi dalam pemasaran dapat efektif, maka si pengirim pesan harus dapat mengetahui siapa yang ingin dicapai dan tanggapan apa yang diinginkan. Pengirim pesan harus mengkodekan pesan mereka dalam suatu cara dengan mempertimbangkan bagaimana si penerima pesan yang dituju biasanya menguraikan kode pesan. Kotler juga mengungkapkan, pengirim pesan harus pula mempertimbangkan media yang efisien sehingga pesan dapat mencapai penerima pesan. Dan pengirim pesan sebaiknya menurut Kotler, dibuka pula saluran untuk menerima tanggapan dari penerima untuk mengetahui dampak dari pesan itu.

Produk bagi radio adalah program atau acara yang ia siarkan. Materi berikut pengemasan suatu program juga harus mempertimbangkan target pendengar. Hal ini untuk positioning dari program tersebut secara khusus dan Radio Trijaya secara umum.

Positioning adalah suatu tiindakan merancang tawaran dan citra perusahaan sehingga menempati suatu menempati suatu posisi yang terbedakan diantara pesaing di dalam benak pelanggan sasarannya. Sementara Al Ries dan Jack Trout sebagaimana dikutip Kotler (2002), menyatakan positioning bukanlah sesuatu yang dilakukan terhadap produk, tapi apa yang dilakukan terhadap pikiran calon pelanggan tentang produk yang dimiliki. Jadi positioning lebih pada mempengaruhi pikiran dari calon pelanggan terhadap produk.

Pengelola Radio Trijaya ingin memposisikan dua programnya, Indonesian First Channel dan Jakarta First Channel sebagai program talkshow yang berkualitas. Dalam setiap acaranya produser program mempersiapkan topiktopik hangat yang menjadi headline media massa untuk diangkat dalam program. Terpenting dalam hal ini adalah menghadirkan narasumber yang kredibel dan kompeten sebagai pembicara dalam program. Untuk mempertajam pembahasan topik, dihadirkan pula moderator dari kalangan jurnalis media 
massa terkenal.

Semakin berkualitas dan tajam pembahasan talkshow dari program, maka semakin menarik bagi pendengar untuk berkomentar dan terlibat dalam program. Hal ini sebagai diungkapkan Program Director, yang juga penyiar Trijaya, Mevi Mevlana.

Mevi mengakui topik yang kurang hangat dan kurang menarik tidak mendapat respons yang baik dari pendengar. Kadang topik yang menarik pun juga kurang mendapat respon. Hal ini menurut Mevi karena penyiar yang kurang menguasai isu sehingga permasalahan yang ada tidak tereksplor dengan baik.

“...Itu bisa aja topik tidak berkenan buat mereka, atau topik membosankan. Atau bisa saja si penyiarnya yang tidak bisa membuat diskusi menarik. Walaupun persiapan untuk topik sudah sudah dilakukan dengan baik, namun ketidakmampuan penyiar itu membuat pendengar kurang tertarik."

Dengan adanya moderator dari kalangan jurnalis media terkenal, diharapkan dapat mengurangi hal-hal demikian. Topik-topik yang diangkat menjadi lebih mendalam dan tajam dalam pembicaraan dengan narasumber. Untuk Indonesia First Channel, Trijaya menghadirkan Didik Supriyanto dari Detik.Com.

Banyaknya respon dari pendengar melalui SMS atau telepon, dapat menjadi tolok ukur bagi pengelola radio apakah program tersebut berhasil, setidaktidaknya dalam menarik minat sekian jumlah pendengar yang terindikasi dari jumlah pengirim SMS dan penelepon dalam suatu program. Semakin banyak pendengar yang berinteraksi, semakin menarik bagi pengiklan untuk memasang iklannya di program itu.

Mevi mengakui banyaknya pendengar yang berinteraksi juga menjadi tolok ukur bagi pengiklan. Mereka ingin mengetahui bagaimana respon pendengar terhadap program itu.

"Biasanya barometernya dari itu. Dari sms pendengar, atau penelepon. Pengiklan jadi mau untuk masuk setelah ada banyaknya respon yang masuk. Biasanya begitu. Kadangkadang pengiklan ingin tahu bagaimana respon pendengar itu baru ia masuk."

Hal yang sama juga dinyatakan oleh Station Manager Trijaya, Tyas Anggoro, Kepala Divisi Marketing Radio MNCN Hardiman Makmur, dan Sales Coordinator Radio MNCN Myrtha.

Dalam berkomunikasi dengan pengiklan, Trijaya dalam hal ini sales dan marketing, melakukannya dengan cara langsung dan tidak langsung. Langsung maksudnya adalah langsung dengan pihak pengiklan. Pengiklan dapat menyampaikan kepada Trijaya tentang pesan yang ingin disampaikan kepada pendengar Trijaya. Dalam hal ini, Trijaya dapat menawarkan berbagai alternatif kepada pengiklan untuk memasarkan produknya melalui Trijaya.

Sementara secara tidak langsung adalah pengiklan berkomunikasi dengan pihak Trijaya melalui perantara dalam hal ini pihak agensi. Pihak agensi menyiapkan strategi komunikasi pemasaran untuk pengiklan. Akibatnya Trijaya harus berhubungan dengan pihak agensi dalam menarik pengiklan tertentu. Karena pengiklan ini memiliki perjanjian dengan pihak agensi. Hal ini sebagaimana diungkapkan Myrtha, Sales Coordinator Trijaya. 
"Kadang-kadang si pengiklan itu kalau tanpa agency, karena mereka tidak mau ribed. Memang agency itu punya ahli dalam strategi komunikasi. Pengiklan inginnya seperti apa, maka yang mengkomunikasikannya itu antara agensi dengan radio. Kalau langsung, kadang-kadang pengiklan tidak ada keterikatan dengan agency. Jadi kadang-kadang agency itu ada keterikatan kontrak mati. Artinya dari segala strategi, media placement, media komunikasi itu udah diikat. Itu biasanya kita tidak bisa menarik pengiklan langsung. Kalau gak ada keterikatan, kita bisa narik mereka langsung..."

Dari uraian analisis strategi komunikasi pemasaran Radio Trijaya dalam mengelola program interaktif, ada beberapa kesimpulan yang bisa dikemukakan:

1. Dalam mengelola programnya, pengelola Trijaya melayani dua pihak yang berkepentingan yaitu pendengar dan pengiklan. Keduanya diperhatikan oleh pengelola secara seimbang.

2. Telepon dan SMS dari pendengar yang masuk dalam program yang disiarkan dapat menjadi tolok ukur apakah program tersebut mendapat respon dari pendengar cukup banyak atau tidak. Pengiklan umumnya tertarik dengan program-program yang banyak mendapat respon dari pendengar.

3. Upaya komunikasi kepada keduanya telah dilakukan oleh pengelola Trijaya dengan cara push strategy dan pull strategy, melalui saluran-saluran bauran komunikasi pemasaran yaitu periklanan, promosi, hubungan masyarakat dan publisitas, personel selling, dan direct selling. Namun belum dilakukan secara maksimal.

4. Sumber Daya Manusia (SDM) sales dan marketing tidak secara komprehensif memahami karakter media radio sehingga kreatifitas dalam melakukan komunikasi pemasaran tidak optimal. Apalagi Trijaya lebih banyak mempercayakan kepada agensi dalam berkomunikasi dengan pengiklannya untuk mempersiapkan strategi komunikasi pemasarannya di media radio.

5. Pengiklan masih cenderung memasang iklannya pada jam-jam prime time.

\section{Daftar Pustaka}

Gazali, Effendi (2002). Penyiaran Alternatif tapi MUTLAK. Sebuah Acuan tentang Penyiaran Publik \& Komunitas. Penerbit Jurusan Ilmu Komunikasi FISIP UI.

List, Dennis (2003). Participative for Local Radio. Wellington: Original Books. Jakarta: Kantor Berita Radio 68H.

Loes de Vos (2000). Searching For The Holy Grail, Images Of Interactive Television. Rotterdam, The Netherlands August. http:/ / www.globalxs.nl/home/l/ ldevos/itvresearch/

Masduki (2004). Menjadi Broadcaster Profesional. Yogyakarta: Pustaka Populer LKiS.

Rusdi, Farid. (2007). Analisa Strategi Komunikasi Pemasaran Program di Radio (Studi Kasus Program Interaktifdi Radio Trijaya FM). Departemen Ilmu Komunikasi, FISIP UI, Jakarta

Sen, Krishna., David T. Hill, (2000). Media, Culture and Politics in Indonesia. Victoria, Oxford University Press. 